\title{
ABCA2 Gene
}

National Cancer Institute

\section{Source}

National Cancer Institute. ABCA2 Gene. NCI Thesaurus. Code C89022.

This gene may be involved in both lipid metabolism and neural development. 